\title{
Description of a new species of Neocressionella Gupta (Hymenoptera: Megachilidae) from North western India
}

\author{
Priyanka Kumari* and Neelima R. Kumar \\ Department of Zoology, Punjab University, Chandigarh- 160014, INDIA \\ *Corresponding author. E-mail: priyanka.dadhwal.chandel@gmail.com \\ Received: August 28, 2014; Revised received: November 24, 2014; Accepted: December 07, 2014
}

\begin{abstract}
A new species, Megachile (Neocressionella) patialensis is described from Patiala, India. Full description of male with their floral relationship, morphological measurements and specimens examined is provided. Knowledge of the life history and nesting habits of Megachile bees will pave the way for their manipulation so that these can be used to increase pollination. Documentation of the genera and species will increase our knowledge of the biodiversity of these bees in the study area.
\end{abstract}

Keywords: Collection, Floral relationship, Leaf cutter bees, Megachile

\section{INTRODUCTION}

Solitary bees construct their nests alone, lay eggs and live aloof without the help of other bees. They show unique architectural capabilities in constructing their nests. They have unique propensity in cutting leaves with their sharp, strong and toothed mandibles. Hence they are called 'leaf cutting bees' for using leaf pieces for inner lining of their nests (Michener, 2007).

Neocressionella was created as a subgenus by Gupta in 1993, before that the species placed in this came under Cressionella Mitchell (Michener, 1962). Michener (2000) placed all non parasitic species in genus Megachile Latrielle and designated Cressionella and Neocressionella as two different subgenera. Michener (2007) described Neocressionella as consisting of large (12-21 mm) megachiliform bees which are black in color in both males and females. The upper tooth of four toothed female was sharply acute and the male was also four toothed with no inferior projection. This showed the reason behind their efficiency in using leaf pieces for nest building. Carina of tergum 6 is not crenulate and is large with sharp lateral tooth.

Sheffield (2013) described a new species Megachile (Megachiloides) chomskyi from Texas, United Stataes. In the same year in 2013 Sheffield and Genero illustrated anew species of leafcutter bee, Megachile (Litomegachile) droegei from Guanatanamo Bay, Cuba. A diagnosis for distinguishing this species from other species of Litomegachile, and full descriptions of the female and male with illustrations was also provided.

Taxonomic studies on subfamily Megachilinae bear a lot of significance. They are efficient pollinators of alfalfa, almond, pear, apple, pigeon pea etc. These bees are even better pollinators than honey bees in some cases because of their efficient flying at a very high speed. Information on the diversity of megachilid bees, their classification, identification and host range will contribute to the understanding of pollination biology of important crop plants. Keeping this in view, bees collected from North western India were studied for their characteristics and identification.

\section{MATERIALS AND METHODS}

The bees were collected from Patiala $\left(30^{\circ} 21^{\prime} 00^{\prime \prime} \mathrm{N}\right.$ and $76^{\circ} 24^{\prime} 00^{\prime \prime} \mathrm{E}$ ), India using sweep nets. After collection, the specimens were transferred to wide mouthed bottles. Cotton swabs wetted with ethyl acetate and glued to the cap of bottle were used for killing the specimen with ethyl acetate vapours. Proper stretching of both wings and legs was done so that every part of specimen is visible. The photography of adult bees was done using Canon D 6 digital camera. Slides were prepared by cutting out the last abdominal segment and boiling it in $10 \% \mathrm{KOH}$ for 10 minutes. Genitalic slides were prepared and photographed with a Stereoscope microscope (RSM 9 fitted with Progress software and CT5 Jenoptik camera). Keys of Oriental fauna given by Bingham (1897), Michener (2000, 2007), Gupta (1999) were followed for identification.

\section{RESULTS AND DISCUSSION}

Systematics:

Megachile patialensis sp. $\mathbf{n}$.

Diagnosis: Pubescence is pale yellow on clypeus and face, integument black throughout except in claws, tegulae and metasomal sterna with light redness. Males can be distinguished from its closest species of 


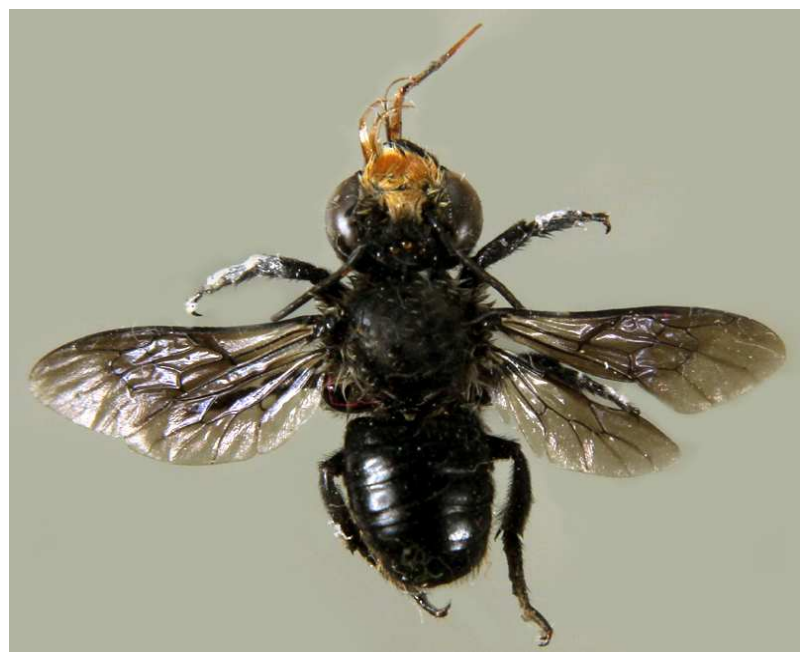

Fig. 1. Megachile patialensis.

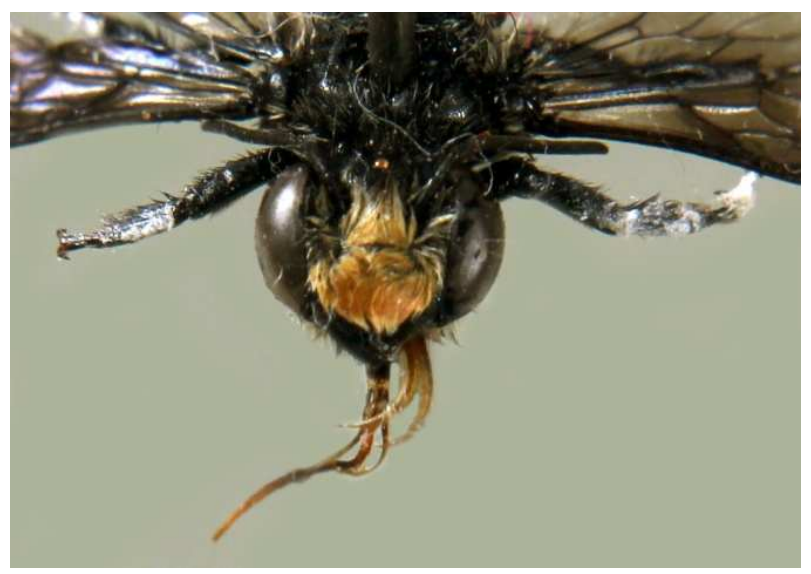

Fig. 2. Body parts (Dorsal habitus, head and wing) of M. patialensis.

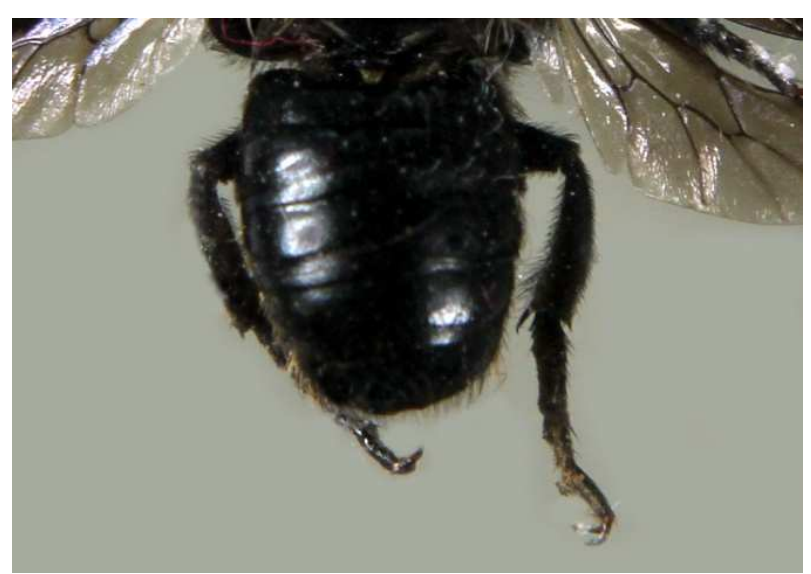

Fig. 3. Metasoma, dorsal view and scopae ventral view of M. patialensis.

Neocressionella i.e. Megachile anthracina by the presence of whitish pubescence on tarsi and claws and the difference in size. Megachile anthracina is larger in size than Megachile patialensis. A particular and important character is apices of gonostipites in genitalia are broader, flattened and different from all identified species viz. Megachile anthracina, Megachile relata, Megachile elizabethae and Megachile carbonaria of this subgenus (Michener, 2007) (Figs. 1-5).

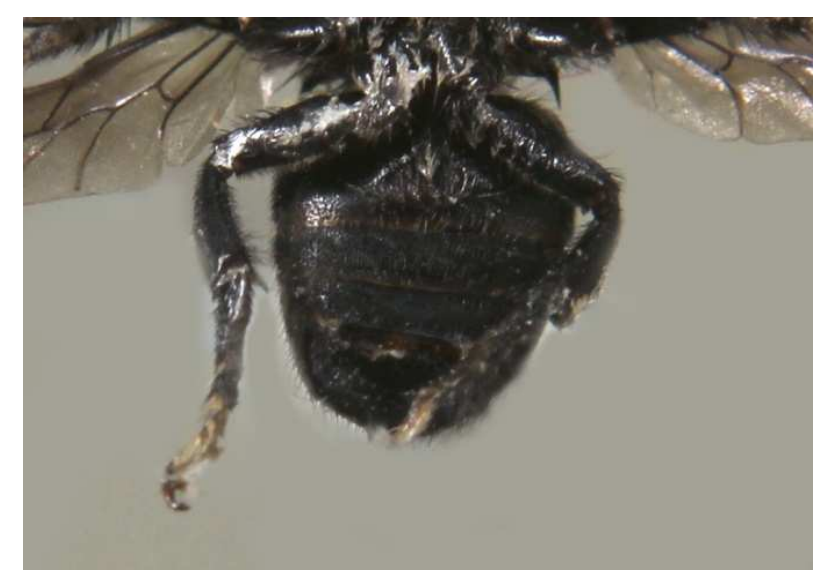

Head: Total body length- $12.14 \mathrm{~mm}$, head width- 4.36 , head length- 2.99, distance between upper margins of eyes- $2.50 \mathrm{~mm}$, distance between lower margins of eyes- $2.53 \mathrm{~mm}$, malar space- $.127 \mathrm{~mm}$, length of mandible - $1.70 \mathrm{~mm}$, length of clypeus- $1.33 \mathrm{~mm}$, basal and apical width of clypeus- $1.72 \mathrm{~mm}$ and $1.42 \mathrm{~mm}, . \mathrm{F}_{1}$ shorter in length to pedicel and $\mathrm{F}_{2}, \mathrm{~F}_{1}=.18 \mathrm{~mm}, \mathrm{~F}_{2}-\mathrm{F}_{11}$ between $.30-.46 \mathrm{~mm}$. It is as broad as thorax, punctured closely and finely, mandibles strong and robust; four dentate, with complete cutting edges between third and fourth inter space. Clypeus broader than longer, notched in between in front and convex behind, punctured closely. Vertex reclining and punctured. Compound eyes divergent, lateral ocelli more closer to the vertex than to the eyes.

Mesosoma: Forewing length- $8.08 \mathrm{~mm}$, Hindwing length- $6.47 \mathrm{~mm}$, marginal cell length-2.21 mm,

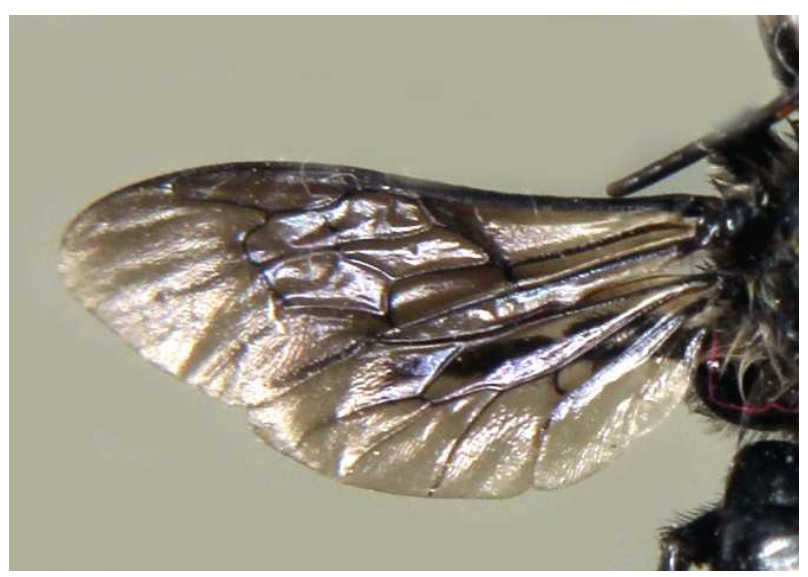

stigma- $.717 \mathrm{~mm}$, length of jugal lobe- $2.25 \mathrm{~mm}$, length of vannal lobe- $3.58 \mathrm{~mm}$, lenth of coxa- .99 $\mathrm{mm}$, trochanter- $.44 \mathrm{~mm}$, femur- $1.88 \mathrm{~mm}$, tibia- 2.26 mm, disti tarsus- $1.73 \mathrm{~mm}$, basi tarsus- $.84 \mathrm{~mm}$. Black hairs ventrally on scutum, wings dark with purplish tinge in the middle and lighter towards the edges; first recurrent vein far from base than second which is close to apex of second submarginal cell, scutum and scutellum deeply and closely punctured. Pronotum imbricate 


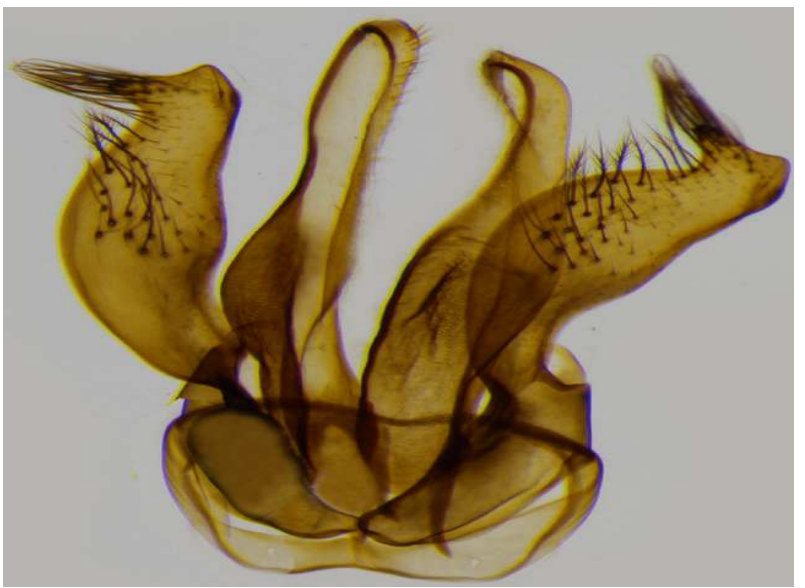

Fig. 4. Genitalia of M. patialensis.

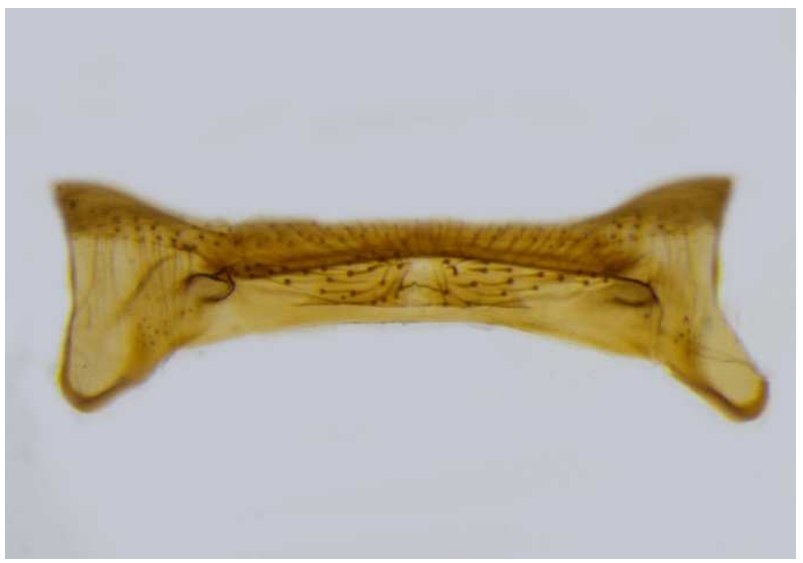

bears certain important morphological and genitalic viz. clypeal margin, gonostipites of genitalia and its pubescence characters which distinguish it and gives it the status of a new species. The study will pave the way for the manipulation so that the bees can be used to increase pollination. Documentation of the genera and species will increase the knowledge of the biodiversity of these bees in study area.

\section{ACKNOWLEDGEMENT}

Support given by UGC BSR (Basic Sciences Research) Meritorious Fellowship with file number F7 150/2007 is greatly acknowledged by the fellow Priyanka Kumari.

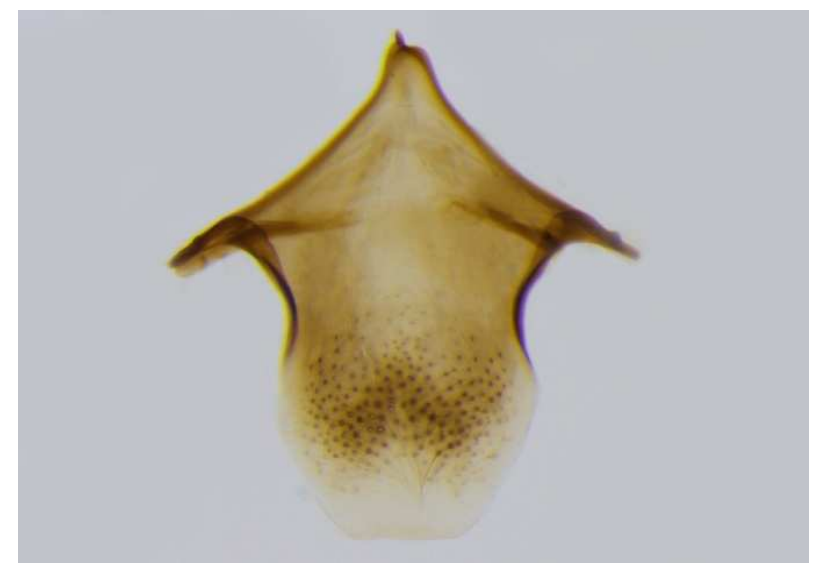

Fig. 5. Sterna 6 and sterna 8 of $M$. patialensis.

with small punctures separated by punctures width, tarsi and claws with whitish pubescence and basal bristles. Metasoma: Breadth of T1- $3.37 \mathrm{~mm}, \mathrm{~T} 2-4.00 \mathrm{~mm}, \mathrm{~T} 3$ - $3.98 \mathrm{~mm}$, T4- $3.54 \mathrm{~mm}$, T5- $2.78 \mathrm{~mm}$, T6- $1.38 \mathrm{~mm}$, T7- $1.08 \mathrm{~mm}$. Tarsal segments whitish; terga black and sternal segments fulvous along basal margins, almost parallel sided with rounded carina emargination, meso and metafemora slightly swollen, Anterior-facing surface of first metasomal tergum finely imbricate, tergum $7^{\text {th }}$ exposed with its apical margin incurved broadly; apex of carina of tergum 6 transverse with shallow median emargination, sterna 2-4 with smooth, translucent and impunctate rims, sterna 4 outcurved on apical margin and punctuate; apices of gonostipites in genitalia broad and flattened.

Etymology: This species has been named after the region from where it was collected i.e., Patiala.

\section{Conclusion}

Megachile patialensis is described as a new species. It

\section{REFERENCES}

Bingham, C.T. (1897). Hymenoptera, Vol. I, Wasps and Bees. In W.T. Blanforded. The fauna of British India, Taylor and Francis (London CCIC): 410-579.

Gupta, R.K. (1999). Taxonomic studies on the Megachilidae of North Western India, Scientific Publisher (India), pp 294.

Michener, C.D. (1962). Observations on the classification of the Bees commonly placed in the genus Megachile.. Journal of the New York Entomological Society, 70:17-29.

Michener, C.D. (2000). The Bees of the World ( $1^{\text {st }}$ Edition), The Johns Hopkins Universitiy Press (Baltimore, USA,), pp 913.

Michener, C.D. (2007). The Bees of the World ( $1^{\text {st }}$ Edition), The Johns Hopkins Universitiy Press (Baltimore, USA), pp 953.

Sheffield, C.S. (2013). A new species of Megachile Latrielle subgenus Megachiloides (Hymenoptera, Megachilidae). Zookeys, 283: 43-58

Sheffield, C.S. and Genero, J.A. (2013). A new species of Megachile (Litomegachile) from Cuba, the Antillis (Hymenoptera: Megachilidae). Journal of Melittology, 19: 1-17. 